International Journal of Instruction e-ISSN: 1308-1470 • www.e-iji.net

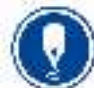

April 2021 • Vol.14, No.2

p-ISSN: 1694-609X

pp. 1021-1036

Article submission code:

20200612112530

Received: $12 / 06 / 2020$

Revision: 13/11/2020

Accepted: 05/12/2020

OnlineFirst: 18/03/2021

\title{
The Correlation between Level of School Happiness and Teacher Autonomy in Jordan
}

\section{Omar T. Al-Bataineh}

Dr., Department of Educational Foundations and Administration, The Hashemite University, Jordan, dr.om.bat@hu.edu.jo

\author{
Ahmad M. Mahasneh \\ Dr., Department of Educational Psychology, The Hashemite University, Jordan, \\ dahmadmahasneh1975@yahoo.com
}

\section{Zohair Al-Zoubi}

Dr., Department of Educational Foundations and Administration, The Hashemite University, Jordan, zohair971@yahoo.com

The present study aimed to investigate the level and correlation of school happiness and teacher autonomy among a sample of Jordanian teachers. The study sample consisted of 1,030 teachers within the Jerash and Mafraq Directorate of Education, with data collected using the School Happiness Scale(SHS) and Teacher Autonomous Behavior Scale(TABS). Results study showed a positive and statistically significant correlation between school happiness and teacher autonomy. Results also showed there were statistically significant differences in the level of school happiness by gender, in favor of female teachers; statistically significant differences in the level of school happiness by school level, in favor of secondary school teachers; and statistically significant differences in the level of school happiness by teacher tenure, in favor of teachers with one to five years of experience. Finally, results also showed statistically significant differences in the level of teacher autonomy attributed to gender, in favor of female teachers; no statistically significant differences in the level of teacher autonomy by school level; and statistically significant differences in the level of teacher autonomy by teacher tenure, in favor of teachers with one to five and six to ten years of experience.

Keywords: happiness, school happiness, jordanian teacher, teacher autonomy, teaching

\section{INTRODUCTION}

The state of happiness is generally qualified as two separate facets, global (overall/general) and episodic (experienced/periodic). The overall facet indicates a generally good level of contentment and satisfaction with life, whereas the periodic trait is dictated by emotional responses to specific experiences (Veenhoven, 2009). 
Numerous studies (e.g., Crede et al., 2007; Fisher, 2010; Judge et al., 2005) have indicated a positive relationship between happiness at work, job performance and satisfaction, whereas burnout and frequent job change indicate the opposite (Iverson, Olekalns, \& Erwin, 1998; Van Katwyk, Fox, Spector, \& Kelloway, 2000).

Researchers' definitions of happiness are varied, including emotions of joy, gladness, and hope, as well as physical and spiritual well-being (Köknel, 1992), life-satisfaction (Huebner, 1991), life-satisfaction and the significance of life(Seligman, Parks \& Steen, 2004), and positive feelings about life (Lyubomirsky, Sheldo \& Schkade, 2005).

Veenhoven (2008) considers happiness to be a result of evaluating life overall, while Seligman (2011) gives a multi-dimensional definition encompassing the meaning of life, positive responses, obligation and accountability, successful relationships, and achievement; studies (Boehm \& Lyubomirsky, 2008; Lyubomirsky, King, \& Diener, 2005; Pan \& Zhou,2013; Schnittker, 2008), revealed evidence of the necessity of success for individuals' happiness.

Despite the interest and number of research studies into school happiness and teacher autonomy in Western countries, this issue has failed to arouse much interest in the Arab world in general and Jordan in particular.

\section{LITERATURE REVIEW}

\section{School happiness}

School happiness is defined as the emotional well-being that results from concordance of expectations and the needs of both staff and students, contingent upon pertinent environmental aspects (Engels, Aelterman, Petegem,\& Schepens, 2004). The importance of a happy school environment is clearly evident for the achievement of effective learning, and encouraging students' abilities (Talebzadeh \& Samkan, 2011).

According to Brird and Markle (2012), a happy school environment is a contributory factor not only to academic success, but continues through life in areas such as good communication skills, continuing success, and self-fulfilment, while Aydin (2016) focuses attention on the demand in child education to emphasize caring and respect for life, nature, and all living things.

Talebzadeh and Samkan (2011) point out the individual, physical, socio-emotional, and instructional factors associated with school happiness; Yildirim (2014)expands this premise, asserting that the following factors contribute to teachers' well-being in the school environment: staff cooperation, assessment and feedback that is fair and helpful, a positive school environment with student-oriented teaching practices, and personal development.

Aelterman, Englels, Van Petegem and Verhaeghe (2007) associate teacher well-being with support from the school principal and colleagues, workload, self-efficacy, parentteacher relations, and positive attitudes towards innovations. In order to more fully understand the complexity of interactions affecting teacher happiness we need to 
examine the wider contexts in which they function, both professionally and socially, and the external boundaries and conciliations.

Some studies assert the importance of providing equipment for sports and physical activities, to encourage student participation and stimulate creativity. Aksu, Demirel and Bektas (2011) considered areas dedicated to artistic and social activities to be essential, and Gür and Kobak-Demir (2016) suggested introducing 'fun-learning' by establishing game-based mathematics laboratories; Kubanc (2014) suggested that student happiness would be improved by the availability of multidisciplinary physical learning equipment.

According to the researchers (Boehm \& Lyubomirsky, 2008; Lyubomirsky, King \& Diener, 2005), people who are happy generally have higher salaries, achieve higher task performance ratings, and are more helpful to their colleagues. Baker (2005) states that in the educational setting, happy teachers nurture happy students who achieve scholastically. Duckworth, Quinn, and Seligman (2009) found teacher positivity and life-satisfaction to be predictors of pupils' academic success, while Turner et al. (2002) showed that humor was more likely to be evident in well organized classes with high student participation. Jennings and Greenberg (2009), reviewing more than 180 studies, stressed that those teachers showing high socio-emotional competence levels developed good teacher-student relations and a supportive classroom atmosphere. Boehm and Lyubomirsky (2008) similarly commented on the importance of a happy environment to encourage and develop student learning. Bride and Markle (2012) emphasize the benefits of a happy school environment not solely in the academic context but in contributing to overall life skills and fulfilment. Conversely, Yucel and Vogt-Yuan (2016) found that if school was an unhappy experience, the effects of low grades, poor pupil-teacher relations, loneliness and anxiety not only result in low self-esteem, but may also contribute to depression and substance abuse. Therefore, the impact of a happy school environment extends beyond schooldays, instilling positive life-skills and optimism for the future. Aydin (2016) specifically mentions the need to teach children awareness, affection, and respect for nature and all forms of life. Since teachers are at the core of learning, the teacher's approach and style are crucially influential in promoting learner happiness and well-being which can motivate learning. A relaxed classroom atmosphere and environment thus allows the teacher to fulfil her comprehensive role as explainer and instructor, planner, facilitator and mediator.

\section{Teacher autonomy}

The term 'autonomy' is derived from the Greek word 'autonmia' (Castle, 2006), which means being independent of control by others. The researchers explains that professional autonomy in the educational domain has a wide interpretation, from selfgovernment at work to an intra-professional organization (Haworth, 1986; Gastle, 2006). Teacher autonomy is defined as both the freedom to act as a professional, and as having the discretionary freedom to organize one's work (Benson, 2010; Runhaar, Konermann, \& Sanders, 2013; Webb, 2002).

Vähäsantanen et al. (2008) focus on the difference between teacher autonomy and the agency concept, which encompasses not simply choices but how they reflect the 
individual's motives, goals, and self-interest, while Yu-hong and Ting(2012) mention the difference between teacher autonomy and organizational autonomy.

Helgoy and Homme (2007) justify teacher autonomy as validating the individual teacher's status in the classroom and the societal context, and Webb et al. (2004) state its strong association with decisions regarding whether or not to remain in the teaching profession. Some researchers state its positive effect on teachers' professional development (Kleinhenz \& Ingvarson, 2004; Lee, 2008).

Although the essential concept is self-determination, taking autonomous or selfdetermined action, teacher autonomy is a multi-faceted complex of philosophical, psychological, sociological, and historical-political aspects. Pfander (1967), explains self-determination from an ego-centric base, whereby self-determined acts are not exclusively the result of internal motivation; the motivation may also be external if the proposals are validated and approved by the individual, in which case since external pressures and influences are inevitable, then autonomy is simply a matter of degree (Ryan \& Deci, 2000).

Kennedy (2010) in the school context, however, sees the set curriculum as the most likely origin of external pressure and influence as teachers seek to implement varying degrees of curricular modification. Implementing the curriculum effectively depends on the degree to which the teacher regards his/her proprietary privileges, a source of concern to curriculum compilers needing teachers' endorsement.

Pearson and Moomaw (2006) see the scope of teacher autonomous behaviour as prime class work procedures concerned with classroom conduct and personal on-the-job discretion. Include in curricular autonomy the selection of activities and materials, plus instructional planning and sequencing (Benson, 2010; Mustafa \& Cullingford, 2008; Pearson \& Moomaw, 2005). The researchers (Öztürk, 2012; Pugh \& Zhao, 2003) noted teacher participation in decision making regarding working conditions and school environment. And researchers see teacher autonomy as control of professional development activities (Powell \& McGowan, 1996; Webb,2002).

\section{Study questions}

The present study attempted to answer the following questions:

Q1: Is there any correlation between school happiness with teacher autonomy?

Q2: Are there any differences in school happiness based on gender, school level, and teacher tenure?

Q3: Are there any differences in teacher autonomy based on gender, school level, and teacher tenure?

\section{METHOD}

\section{Study design}

In the current study, the descriptive approach was used. To identify the statistically significant differences in the level of school happiness and teacher autonomy MONOVA 
was used. Pearson correlation was used to investigate the relationship between school happiness and teacher autonomy.

\section{Study sample}

The study population consisted of all teachers within the Jerash and Mafraq Directorate of Education during the school year 2019/2020. The study sample consisted of 1,030 teachers, chosen by available sampling method, of whom 558(54.2\%) were male and $472(45.8 \%)$ female; $443(43 \%)$ were teaching at primary school level, and 587(57\%)at secondary level; $345(33.5 \%)$ teachers had1-5 years of teaching experience, $348(33.8 \%)$ $6-10$ years, and $337(32.7 \%) 10$ years or more. The study sample age ranged from 25 to 50 years.

\section{Study instruments}

The School Happiness Scale and Teacher Autonomy Scale were used.

\section{School Happiness Scale (SHS)}

The SHS was developed by Sezer and Can (2019) and consists of 26 items; it measures five dimensions of school happiness according to the five-point Likert scale from $1=$ strongly disagree to $5=$ strongly agree. The dimensions are physical activity equipment (4 items, Cronbach alpha $=0.73$ ), learning environment $(7$ items, Cronbach alpha= 0.87), collaboration ( 8 items, Cronbach alpha $=0.82$ ), activities $(3$ items, Cronbach alpha $=$ $0.70)$, and school management (4 items, Cronbach alpha $=0.94)$. The overall Cronbach alpha for SHS was 0.93 .

These authors calculated the reliability of the SHS using Cronbach alpha $(0.79,0.84$, $0.79,0.78$ and 0.84 ) respectively for physical equipment, learning environment, collaboration, activities, and school management. The Cronbach alpha for SHS reliability was 0.90 .

\section{Teacher Autonomy Behavior Scale (TABS)}

TABS was developed by Evers, Verboon and Klaeijsen (2017), and consists of 20 items, measured on a seven-point Likert scale from $(1=$ almost never $)$ to $(7=$ almost always). It measures four dimensions of teacher autonomous behavior: primary work processes in the class( 6 items, Cronbach alpha $=0.87)$, curriculum implementation $(6$ items, Cronbach alpha $=0.89$ ), participation in decision making at school (4 items, Cronbach alpha $=0.82$ ), and professional development (4 items, Cronbach alpha= 0.94).

In the present study the authors calculated the reliability of the TABS finding Cronbach alpha $0.79,0.83,0.82$ and 0.89 respectively for primary work processes in the classroom, curriculum implementation, participation in decision making at school, and professional development.

\section{Data collection and analysis}

The study scales was translated from English into Arabic and the accuracy and integrity of the translation was verified; a pilot study was carried out and completed by 50 
teachers to ensure the clarity of the items in the Arabic language, and the wording of some of the items was modified in the light of the teachers' comments. The researchers visited the schools included in the study sample, the scales were distributed to the teachers, and the data collected after two months. The researchers entered the data using SPSS, and the analysis and answers to the study questions, descriptive statistics, and correlation coefficients were achieved using MANOVA.

\section{FINDINGS}

\section{Q1: Is there any correlation between school happiness with teacher autonomy?}

To discover the correlation between school happiness and teacher autonomy among Jordanian teachers, Pearson correlation tables were used, as shown in Table 1.

Table 1

Pearson correlation matrix between school happiness and teacher autonomy

\begin{tabular}{llllll}
\hline Variables & $\begin{array}{l}\text { Primary work } \\
\text { process in } \\
\text { class }\end{array}$ & $\begin{array}{l}\text { Curriculum } \\
\text { implementation }\end{array}$ & $\begin{array}{l}\text { Participation in } \\
\text { decision making } \\
\text { at school }\end{array}$ & $\begin{array}{l}\text { Professional } \\
\text { development }\end{array}$ & $\begin{array}{l}\text { Teacher } \\
\text { autonomy }\end{array}$ \\
\hline Physical equipment & $0.23^{*}$ & $0.29^{*}$ & $0.31^{*}$ & $0.33^{*}$ & $0.35^{*}$ \\
\hline Learning environment & $0.49^{*}$ & $0.44^{*}$ & $0.50^{*}$ & $0.49^{*}$ & $0.58^{*}$ \\
\hline Collaboration & $0.44^{*}$ & $0.48^{*}$ & $0.57^{*}$ & $0.47^{*}$ & $0.59^{*}$ \\
\hline Activities & $0.30^{*}$ & $0.35^{*}$ & $0.45^{*}$ & $0.47^{*}$ & $0.47^{*}$ \\
\hline School management & $0.24^{*}$ & $0.25^{*}$ & $0.38^{*}$ & $0.19^{*}$ & $0.32^{*}$ \\
\hline School happiness & $0.48^{*}$ & $0.50^{*}$ & $0.61^{*}$ & $0.54^{*}$ & $0.64^{*}$ \\
\hline
\end{tabular}

Table 1 shows a positive and statistically significant correlation between school happiness and teacher autonomy; the value of the correlation coefficient was $(r=0.64)$. The results also show a positive correlation between the dimensions of the school happiness scale and the dimensions of the teacher autonomy scale, with values of the correlation coefficient ranging from $(\mathrm{r}=0.19)$ to $(\mathrm{r}=0.59)$.

Q2: Are there any statistically significant differences in the level of school happiness attributed to teacher's gender, school level, and teacher tenure?

The means and standard deviations for levels of school happiness attributed to teacher gender, school level, and teacher tenure are shown in Table 2.

Table 2

Mean(M), standard deviation (SD), and level of school happiness based on gender, school level and number of teacher tenure

\begin{tabular}{|c|c|c|c|c|c|c|c|c|c|c|c|c|c|}
\hline \multirow{2}{*}{\multicolumn{2}{|c|}{ Variable Level }} & \multicolumn{2}{|l|}{$\mathrm{PE}$} & \multicolumn{2}{|l|}{ LE } & \multicolumn{2}{|l|}{$\mathrm{C}$} & \multicolumn{2}{|l|}{ A } & \multicolumn{2}{|l|}{ SM } & \multicolumn{2}{|l|}{$\mathrm{SH}$} \\
\hline & & $\bar{M}$ & SD & M & SD & $\mathrm{M}$ & SD & M & SD & $\mathrm{M}$ & SD & $\mathrm{M}$ & SD \\
\hline \multirow[t]{2}{*}{ Gender } & Male & 3.57 & .96 & 3.89 & .69 & 4.21 & .57 & 3.89 & .84 & 4.49 & .62 & 4.03 & .55 \\
\hline & Female & 3.84 & .67 & 4.17 & .47 & 4.29 & .38 & 3.98 & .77 & 4.45 & .51 & 4.18 & .34 \\
\hline \multirow{2}{*}{$\begin{array}{l}\text { School } \\
\text { level }\end{array}$} & Primary & 3.67 & .86 & 4.01 & .65 & 4.17 & .56 & 4.01 & .81 & 4.38 & .49 & 4.07 & .49 \\
\hline & Secondary & 3.71 & .84 & 4.02 & .58 & 4.30 & .43 & 3.88 & .81 & 4.54 & .63 & 4.12 & .45 \\
\hline \multirow{3}{*}{$\begin{array}{l}\text { Teacher } \\
\text { tenure }\end{array}$} & $1-5$ & 3.79 & .92 & 4.09 & .66 & 4.34 & .55 & 4.09 & .77 & 4.70 & .46 & 4.22 & .49 \\
\hline & $6-10$ & 3.84 & .82 & 4.09 & .59 & 4.25 & .43 & 3.91 & .75 & 4.38 & .53 & 4.13 & .45 \\
\hline & More than 10 & 3.44 & .75 & 3.87 & .56 & 4.15 & .48 & 3.80 & .89 & 4.33 & .65 & 3.95 & .45 \\
\hline
\end{tabular}

Note: PE- Physical Equipment, LE- Learning Environment, C- Collaboration, A- Activities, SM-

School Management, SH- School Happiness 
To discover whether the mean differences are statistically significant, multivariate analysis of variance (MANOVA)was applied, with the results shown in Table 3.

Table 3

MANOVA result of the level of school happiness based on gender, school level and years of teacher tenure

\begin{tabular}{|c|c|c|c|c|c|c|c|}
\hline Source & Dependent variable & $\begin{array}{l}\begin{array}{l}\text { Sum } \\
\text { squares }\end{array} \\
\end{array}$ & of & $\mathrm{DF}$ & $\begin{array}{l}\text { Square } \\
\text { Means }\end{array}$ & $\mathrm{F}$ & Sig \\
\hline \multirow[t]{6}{*}{ Gender } & Physical equipment & 12.153 & & 1 & 12.153 & 17.623 & 0.00 \\
\hline & Learning environment & 14.840 & & 1 & 14.840 & 41.424 & 0.00 \\
\hline & Collaboration & 0.461 & & 1 & 0.461 & 1.926 & 0.16 \\
\hline & Activities & 0.640 & & 1 & 0.640 & 0.984 & 0.32 \\
\hline & School management & 2.332 & & 1 & 2.332 & 7.643 & 0.00 \\
\hline & School happiness & 2.689 & & 1 & 2.689 & 12.673 & 0.00 \\
\hline \multirow{6}{*}{$\begin{array}{l}\text { School } \\
\text { level }\end{array}$} & Physical equipment & 0.631 & & 1 & 0.631 & 0.915 & 0.33 \\
\hline & Learning environment & 0.070 & & 1 & 0.070 & 0.194 & 0.66 \\
\hline & Collaboration & 4.046 & & 1 & 4.046 & 16.906 & 0.00 \\
\hline & Activities & 4.861 & & 1 & 4.861 & 7.475 & 0.00 \\
\hline & School management & 5.272 & & 1 & 5.272 & 17.281 & 0.00 \\
\hline & School happiness & 0.830 & & 1 & 0.830 & 3.911 & 0.04 \\
\hline \multirow{6}{*}{$\begin{array}{l}\text { Teacher } \\
\text { tenure }\end{array}$} & Physical equipment & 25.501 & & 2 & 12.751 & 18.490 & 0.00 \\
\hline & Learning environment & 6.723 & & 2 & 3.362 & 9.384 & 0.00 \\
\hline & Collaboration & 5.563 & & 2 & 2.782 & 11.624 & 0.00 \\
\hline & Activities & 14.387 & & 2 & 7.193 & 11.061 & 0.00 \\
\hline & School management & 27.226 & & 2 & 13.613 & 44.623 & 0.00 \\
\hline & School happiness & 9.774 & & 2 & 4.887 & 23.033 & 0.00 \\
\hline \multirow[t]{6}{*}{ Error } & Physical equipment & 706.853 & & 1025 & 0.690 & & \\
\hline & Learning environment & 367.194 & & 1025 & 0.358 & & \\
\hline & Collaboration & 245.286 & & 1025 & 0.239 & & \\
\hline & Activities & 666.617 & & 1025 & 0.650 & & \\
\hline & School management & 312.696 & & 1025 & 0.305 & & \\
\hline & School happiness & 217.470 & & 1025 & 0.212 & & \\
\hline \multirow{6}{*}{$\begin{array}{l}\text { Corrected } \\
\text { total }\end{array}$} & Physical equipment & 752.023 & & 1029 & & & \\
\hline & Learning environment & 393.046 & & 1029 & & & \\
\hline & Collaboration & 256.350 & & 1029 & & & \\
\hline & Activities & 687.450 & & 1029 & & & \\
\hline & School management & 346.867 & & 1029 & & & \\
\hline & School happiness & 233.249 & & 1029 & & & \\
\hline
\end{tabular}

Table 3shows statistically significant differences in the level of school happiness attributed to gender (Wilks Lambda $=0.932, F=14.894$, Sig=0.00), in favor of female teachers, in the level of school happiness attributed to school level (Wilks Lambda= 0.932, $\mathrm{F}=14.904, \mathrm{Sig}=0.00$ ), in favor of secondary school teachers, and in the level of school happiness attributed to the teacher tenure(Wilks Lambda $=0.879, \mathrm{~F}=13.547$, Sig=0.00). Significant differences by number of years of teaching were identified using the Scheffe post hoc test; the results are shown in Table 4. 
Table 4

Scheffe test results of school happiness level according to the teacher tenure

\begin{tabular}{llllll}
\hline Variable & Level & Mean & $1-5$ & $6-10$ & More than 10 \\
\hline \multirow{3}{*}{ Teacher tenure } & $1-5$ & 4.22 & & 0.9 & 0.27 \\
\cline { 2 - 6 } & $6-10$ & 4.13 & -0.9 & & 0.18 \\
\cline { 2 - 6 } & More than 10 & 3.95 & -0.27 & 0.9 & \\
\hline
\end{tabular}

Table 4 shows statistically significant differences in the level of school happiness attributed to teacher tenure in favor of teachers who have one to five years teaching experience, compared to teachers who have six to ten years and more than ten years' teaching experience. The table also shows statistically significant differences in the level of school happiness in favor of teachers with six to ten years' teaching experience compared to teachers who have more than ten years' experience.

Q3: Are there any statistically significant differences in the level of teacher autonomy attributed to teacher gender, school level, an teacher tenure?

To find the statistically significant differences in the level of teacher autonomy attributed to teacher's gender, school level, and teacher tenure, means and standard deviations were collated as shown in Table 5. Multivariate analysis of variance(MANOVA) was then applied, with the results as shown in Table 6.

Table 5

Means(M), standard deviation(SD), and level of teacher autonomy based on gender, school level and teacher tenure

\begin{tabular}{|c|c|c|c|c|c|c|c|c|c|c|c|}
\hline Variable & Level & PWP & & CI & & PDM & & PD & & TA & \\
\hline \multirow[t]{2}{*}{ Gender } & Male & 5.70 & .77 & 5.74 & .91 & 5.79 & .94 & 5.60 & .98 & 5.71 & .75 \\
\hline & Female & 5.93 & .68 & 6.10 & .64 & 5.91 & .73 & 5.87 & .86 & 5.96 & .53 \\
\hline \multirow{2}{*}{$\begin{array}{l}\text { School } \\
\text { level }\end{array}$} & Primary & 5.79 & .71 & 5.93 & .76 & 5.87 & .85 & 5.85 & .90 & 5.86 & .64 \\
\hline & Secondary & 5.82 & .76 & 5.89 & .86 & 5.83 & .86 & 5.62 & .96 & 5.80 & .70 \\
\hline \multirow{3}{*}{$\begin{array}{l}\text { Teacher } \\
\text { tenure }\end{array}$} & $1-5$ & 5.83 & .69 & 6.06 & .69 & 6.00 & .70 & 5.67 & .93 & 5.90 & .58 \\
\hline & $6-10$ & 5.85 & .69 & 5.97 & .80 & 5.87 & .85 & 5.84 & .93 & 5.89 & .70 \\
\hline & More than 10 & 5.74 & .83 & 5.68 & .90 & 5.65 & .96 & 5.65 & .94 & 5.69 & .73 \\
\hline
\end{tabular}

Note: PWP- Primary work process in the class, CI- Curriculum implementation, PDMParticipation in decision making at school, PD-Professional development, SM-School Management, TA-Teacher autonomy 
Table 6

MANOVA results of the level of teacher autonomy levels based on gender, school level and teacher tenure

\begin{tabular}{|c|c|c|c|c|c|c|}
\hline Source & Dependent variable & $\begin{array}{l}\text { Sum of } \\
\text { squares }\end{array}$ & DF & $\begin{array}{l}\text { Mean of } \\
\text { squares }\end{array}$ & $\mathrm{F}$ & Sig \\
\hline \multirow[t]{5}{*}{ Gender } & Primary work process in the class & 11.685 & 1 & 11.685 & 21.538 & 0.00 \\
\hline & Curriculum implementation & 24.676 & 1 & 24.676 & 39.252 & 0.00 \\
\hline & Participation in decision making at school & 1.083 & 1 & 1.083 & 1.500 & 0.22 \\
\hline & Professional development & 18.568 & 1 & 18.568 & 21.762 & 0.00 \\
\hline & Teacher autonomy & 12.857 & 1 & 12.857 & 28.838 & 0.00 \\
\hline \multirow{5}{*}{$\begin{array}{l}\text { School } \\
\text { level }\end{array}$} & Primary work process in the class & 0.317 & 1 & 0.317 & 0.585 & 0.44 \\
\hline & Curriculum implementation & 0.402 & 1 & 0.402 & 0.639 & 0.42 \\
\hline & Participation in decision making at school & 0.474 & 1 & 0.474 & 0.656 & 0.41 \\
\hline & Professional development & 12.497 & 1 & 12.497 & 14.647 & 0.00 \\
\hline & Teacher autonomy & 0.750 & 2 & 0.750 & 1.682 & 0.19 \\
\hline \multirow{5}{*}{$\begin{array}{l}\text { Teache } \\
\text { r tenure }\end{array}$} & Primary work process in the class & 0.992 & 2 & 0.496 & 0.914 & 0.40 \\
\hline & Curriculum implementation & 17.690 & 2 & 8.845 & 14.070 & 0.00 \\
\hline & Participation in decision making at school & 18.501 & 2 & 9.251 & 12.813 & 0.00 \\
\hline & Professional development & 5.726 & 2 & 2.863 & 3.356 & 0.03 \\
\hline & Teacher autonomy & 5.918 & 2 & 2.959 & 6.637 & 0.00 \\
\hline \multirow[t]{5}{*}{ Error } & Primary work process in the class & 556.100 & 1025 & 0.543 & & \\
\hline & Curriculum implementation & 644.378 & 1025 & 0.629 & & \\
\hline & Participation in decision making at school & 740.038 & 1025 & 0.722 & & \\
\hline & Professional development & 874.555 & 1025 & 0.853 & & \\
\hline & Teacher autonomy & 456.988 & 1025 & 0.446 & & \\
\hline \multirow{5}{*}{$\begin{array}{l}\text { Correct } \\
\text { ed total }\end{array}$} & Primary work process in the class & 570.310 & 1029 & & & \\
\hline & Curriculum implementation & 696.654 & 1029 & & & \\
\hline & Participation in decision making at school & 762.458 & 1029 & & & \\
\hline & Professional development & 913.319 & 1029 & & & \\
\hline & Teacher autonomy & 480.397 & 1029 & & & \\
\hline
\end{tabular}

Table 6 shows statistically significant differences in the level of teacher autonomy attributed to the gender variable(Wilks Lambda $=0.938, F=16.796, \mathrm{Sig}=0.00$ ), in favor of female teachers. There were no statistically significant differences in the level of teacher autonomy attributed to either the school level (Wilks Lambda=0.974, F=6.792, $\mathrm{Sig}=0.00)$. Table 6 also shows statistically significant differences in the level of teacher autonomy attributed to the teacher tenure (Wilks Lambda=0.914, F=11.773, Sig=0.00). To identify significant differences between the teacher tenure, the Scheffe post hoc test was used, with results as shown in Table 7.

Table 7

Scheffe test results of teacher autonomy level according to teacher tenure

\begin{tabular}{llllll}
\hline Variable & Level & Mean & 1-5 years & 6-10 years & More than 11 years \\
\hline Teacher & $1-5$ & 5.90 & & & 0.21 \\
\cline { 2 - 6 } tenure & $6-10$ & 5.89 & & & 0.20 \\
\cline { 2 - 6 } & More than 10 & 5.69 & -0.21 & 0.20 & \\
\hline
\end{tabular}

Table 7 shows significant differences in the level of teacher autonomy attributed to teacher tenure in favor of teachers with one to five and six to ten years' experience, compared to teachers with eleven or more years of teaching experience. 


\section{DISCUSSION}

The current study aimed to identify if there any significant differences in these levels of school happiness and teacher autonomy by gender, school level, and teacher tenure among a sample of 1,030 Jordanian teachers, and whether there are significant differences in these levels by gender, school level, and years of teacher tenure. It also aimed to investigate the relationship between school happiness and teacher autonomy.

The results of the current study showed there was a positive and statistically significant correlation between the level of school happiness and the level of teacher autonomy among Jordanian teachers. The researchers attribute this result to the fact that happiness has a strong positive effect on an individual's behavior, including positive thinking; individuals think positively when they are happy and more confident in themselves, and they are ready to face problems and make appropriate decisions, which all contribute to strengthening teachers' autonomy. This something that teachers should be able to recognize and is one of the main features in their personality, controlling most of their behavior in a large number of different life situations because of its effective role in enabling them to face the difficulties and challenges of life.

Boehm and Lyubomirsky (2008) found employee happiness levels to be directly related to the amount of social support given by colleagues and management and higher levels result from helpful and supportive interactions with others. The results of studies (Aelterman et al., 2007; Yildirim, 2014) found that teachers' well-being in school was increased by good parent-teacher relations, staff cooperation, supportive school principal and colleagues, as well as fair and helpful assessment and feedback.

Buragohain and Hazarika (2015) found that the high levels of school happiness for teachers increases their level of job satisfaction. Tablebzadeh and Samkan (2011) found that students' and teachers' school happiness was increased by practical changes including a green area within the school grounds, paying attention to the nutritional value of school meals, attracting pupils' interest in the classroom by introducing a variety of appropriate educational aids, providing stimulating and practical art classes in the school program, and establishing sports teams to include teachers as well as students.

Second, there were statistically significant differences in the level of school happiness due to gender, in favor of female teachers. This result may be explained by the fact that female teachers are more able to dedicate themselves to their work in school without being tired by extra responsibilities and economic worries for the future, since in the prevailing culture in Jordanian society, the men are responsible for supporting the family financially. In their study of school happiness levels among Turkish teachers, Sezer and Can (2019) found no statistically significant difference was found in school happiness levels attributable to gender variable. Mertoglu (2018) found a generally high happiness level among Turkish teachers but no statistically significant differences attributable to any of the variables - age, gender or marital status. Buragohain and Hazarika (2015) found that the no statically significant differences in the levels of school happiness attribute to gender variable. 
In addition, parents and the local community are usually more assertive in dealing with male teachers than female teachers, for considerations imposed by the culture, making male teachers more vulnerable to the pressure, criticism, and interference of parents in their teaching methods and their interaction with students; this may be considered as an important contributory factor to female teachers having higher levels of school happiness than their male counterparts.

Third, there were statistically significant differences in the level of school happiness by level of school, in favor of secondary school teachers. This result may be explained by the fact that secondary school teachers are able to harmonize and interact with their class/group of pupils, which enhances the individual's level of motivation and happiness in staying with the group; the high level of homogeneity among members of one group leads to a high level of contact between its members, which enhances the level of school happiness. The interaction between them is positive, so that their behavior is characterized by cooperation and friendliness, and a high level of interaction. Sezer and Can (2019) found that the there are statistically significant differences in the of school happiness due to type of school. The mean scores of school happiness among primary school was higher than secondary schools.

Fourth, there were statistically significant differences in the level of school happiness due to teacher tenure, in favor of teachers with less than five years' teaching experience. This result may be explained by the fact that teachers with less teaching experience tend to seek stability and job security, are more active in the school environment, and are more enthusiastic and motivated in their teaching duties, all of which factors are reflected in their sense of school happiness.

five, there were statistically significant differences in the level of teacher autonomy by gender, in favor of female teachers. The researchers attribute this result to the enrolment of female teachers, stemming from their internal desire and motivation, which makes them more effective in the teaching profession than male teachers. This enhances their self-confidence and the self-realization achieved through successfully playing the role expected of female teachers. Yazici (2016) and Karabacak (2014) found no statistically significant difference was found in teachers autonomy levels attributable to gender variable. While Üzüm (2014) found that the level of teachers autonomy among males teachers was higher than of females teachers.

Six, there were no statistically significant differences in the level of teacher autonomy due to the school level. The researchers attribute this result to the nature of the common professional conditions for both primary and secondary schools. In addition, the members of the study sample are from the same community, and collectively share a common lifestyle and the same profession, so the nature of social and professional interactions between teachers does not differ according to the school level. Yazici (2016) found a statistically significant difference in teachers autonomy levels attributable to school level variable, in favor of elementary school teachers. While Rudolph (2006) and Moomaw (2005) found a statistically significant difference in teachers autonomy levels attributable to school type variable, in favor of secondary school teachers. 
seven, there were statistically significant differences in the level of teacher autonomy according to teacher tenure, in favor of teachers who have less than ten years' experience. The researchers attribute this result to the fact that teachers with less experience in teaching are motivated to perform their work in school effectively and efficiently, and feel more freedom than teachers who have long years of experience. Likewise, teachers who have less than ten years of experience set special goals for themselves and strive to achieve them, and they need to participate in vocational courses in order to achieve material gains. In addition to which, participation in vocational courses is very important for teachers' bids for promotion and tenure opportunities. Wright et al. (2018) found that there are statistically significant differences in the level of teacher autonomy according to teacher years of experiences in teaching, in favor of teachers who have 5-9 years of teaching experiences.

\section{CONCLUSION}

This study aimed to identify if there any significant differences in these levels of school happiness and teacher autonomy by gender, school level, and teacher tenure among a sample of Jordanian teachers, and whether there are significant differences in these levels by gender, school level, and years of teacher tenure. It also aimed to investigate the relationship between school happiness and teacher autonomy. Results of the study showed there was a positive and statistically significant correlation between the level of school happiness and the level of teacher autonomy. There were statistically significant differences in the level of school happiness by gender, in favor of female teachers; statistically significant differences in the level of school happiness by school level, in favor of secondary school teachers; and statistically significant differences in the level of school happiness by teacher tenure, in favor of teachers with one to five years of experience. Results also showed statistically significant differences in the level of teacher autonomy attributed to gender, in favor of female teachers; no statistically significant differences in the level of teacher autonomy by school level; and statistically significant differences in the level of teacher autonomy by teacher tenure, in favor of teachers with one to five and six to ten years of experience. The present study sample was limited to Jordanian teachers with in the Jerash and Mafraq Directorate of Education, whereas future research may be undertaken in other directorates and with other variables associated with school happiness and teacher autonomy, such as teacher self-efficacy.

\section{REFERENCES}

Aelterman, A., Engels, N., Van Petegem, K., \& Verhaeghe, J. P. (2007). The wellbeing of teachers in Flanders: The importance of a supportive school culture. Educational Studies, 3(33), 285-298.

Aksu, Ö. V., Demirel., Ö., \&Bektaş, N. (2011). A research on reinforcement elements in elementary school gardens Trabzon city. Journal of Art and Design, 1(3), 243-254.

Aydın, A. (2016). Happiness. Ankara: Pegema Publishing. 
Bakker, A. B. (2005). Flow among music teachers and their students: The crossover of peak experiences. Journal of Vocational Behavior, 66, 26-44.

Benson, P. (2010). Teacher education and teacher autonomy: Creating spaces for experimentation in secondary school English language teaching. Language Teaching Research, 14(3), 259-275.

Bird, J. M., \& Markle, R. S. (2012). Subjective well-being in school environments: promoting positive youth development through evidence based assessment and intervention. American Journal of Orthopsychiatry, 82, 61-66.

Boehm, J., \& Lyubomirsky, S. (2008). Does happiness promote career success? Journal of Career Assessment, 16(1), 101-116.

Castle, K. (2006). Autonomy through pedagogical research. Teaching and Teacher Education, 22(8),1094-1103.

Buragohain, P., \& Hazarika, M. (2015). Happiness level of secondary school teachers in relation to their job satisfaction. International Journal of Humanities and Social Sciences, 21(3), 19-36.

Crede, M., Chernyshenko, O. S., Stark, S., Dalal, R. S., \& Bashshur, M. (2007). Job satisfaction as mediator: An assessment of job satisfaction's position within the homological network. Journal of Occupational and Organizational Psychology, 80, 515-538.

Duckworth, A. L., Quinn, P. D., \& Seligman, M. E. P. (2009). Positive predictors of teacher effectiveness. The Journal of Positive Psychology, 4, 540-547.

Engels, N., Aelterman, A., Petegem, K. V., \& Schepens, A. (2004). Factors which influence the well-being of pupils in Flemish secondary schools. Educational Studies, $30,127-143$.

Evers, A., Verboon, P., \& Klaeijsen, A. (2017). The development and validation of a scale measuring teacher autonomous behavior. British Educational Research Journal, 43(4), 805-821.

Fisher, C. D. (2010). Happiness at work. International Journal of Management Reviews, 12, 384-412.

Gür, H., \& Kobak-Demir, M. (2016). The views of the teacher candidates about the project of game based mathematics learning laboratory. Journal of Electronic Science and Mathematics Education, 10(1), 415- 438.

Haworth, L. (1986).Autonomy. New Haven, CT, Yale University Press.

Helgøy, I.,\& Homme, A. (2007).Towards a new professionalism in school? A comparative study of teacher autonomy in Norway and Sweden. European Educational Research Journal, 6(3), 232-249. 
Huebner, E. S. (1991). Correlates of life satisfaction in children. School Psychology Quarterly, 6(2), 103-111.

Iverson, R. D., Olekalns, M., \& Erwin, P. J. (1998). Affectivity, organizational stressors, and absenteeism: A causal model of burnout and its consequences. Journal of Vocational Behavior, 52(1), 1-23.

Jennings, P. A., \& Greenberg, M. T. (2009). The pro-social classroom: Teacher social and emotional competence in relation to student and classroom outcomes. Review of Educational Research, 79, 491-525.

Judge, T. A., Bono, J. E., Erez, A., \& Locke, E. A. (2005). Core self-evaluations and job and life satisfaction: The role of self-concordance and goal attainment. Journal of Applied Psychology, 90, 257-268.

Karabacak, M. (2014). The relationship between the autonomy perceptions and selfefficacy perceptions of the teachers working in general high school in Ankara. Unpublished Master's Thesis. Ankara University , Ankara.

Kennedy, M. M. (2010). Attribution error and the quest for teacher quality. Educational Researcher, 39(8), 591-598.

Kleinhenz, E., \& Ingvarson, L. (2004). Teacher accountability in Australia: Current policies and practices and their relation to the improvement of teaching and learning. Research Papers in Education, 19(1), 31-49.

Köknel, Ö. (1992). Living full. Istanbul: Golden Books.

Kubanç, Y. (2014). Examination of physical status of preschool education institutions. International Journal of Social Research, 7(31), 676-688.

Lee, I. (2008). Understanding teachers' written feedback practices in Hong Kong secondary classrooms. Journal of Second Language Writing, 17(2), 69-85.

Lyubomirsky, S., King, L., \& Diener, E. (2005). The benefits of frequent positive affect: Does happiness lead to success? Psychological Bulletin, 131(6), 803-855.

Lyubomirsky, S., Sheldon, K. M., \& Schkade, D. (2005). Pursuing happiness: The architecture of sustainable change. Review of General Psychology, 9, 111-131.

Mertoglu, M. (2018). Happiness level of teachers and analysis its relation with some variables. Asian Journal of Education and Training, 4(4), 396-402.

Moomaw, W. E. (2005). Teacher-perceived autonomy: a construct validation of the teacher autonomy scale. Unpublished Doctoral dissertation. The University of West Florida.

Mustafa, M., \& Cullingford, C. (2008). Teacher autonomy and centralized control: The case of textbooks. International Journal of Educational Development, 28(1), 81-88. 
Öztürk, I. H. (2012). Teacher's role and autonomy in instructional planning: The case of secondary school history teachers with regard to the preparation and implementation of annual instructional plans. Educational Sciences: Theory \& Practice, 12(1), 295-299.

Pan, J., \& Zhou, W. (2013). Can success lead to happiness? The moderators between career success and happiness. Asia Pacific Journal of Human Resources, 51(1), 63-80.

Pearson, L., \& Moomaw, W. (2005). The relationship between teacher autonomy and stress, work satisfaction, empowerment, and professionalism. Educational Research Quarterly, 29(1), 38-54.

Pearson, L., \& Moomaw, W. (2006).Continuing validation of the teaching autonomy scale. Journal of Educational Research, 100(1), 44-51.

Pfander, A. (1967). Phenomenology of willing and motivation (H. Spiegelberg, Trans.). Evanston, IL: Northwestern University Press (Original work published 1908).

Powell, J., \& McGowan, T. (1996). In search of autonomy: Teachers' aspirations and expectations from a school-university collaborative. Teaching and Teacher Education, 12(3), 249-260.

Pugh, K. J., \& Zhao, Y. (2003). Stories of teacher alienation: A look at the unintended consequences of efforts to empower teachers. Teaching and Teacher Education, 19(2), 187-201.

Rudolph, L. (2006). Decomposing teacher autonomy: A study investigating types of teacher autonomy and how it relates to job satisfaction. Unpublished Doctoral dissertation. University of Pennsylvania, Pennsylvania.

Runhaar, P., Konermann, J., \& Sanders, K. (2013.) Teachers' organizational citizenship behaviour: Considering the roles of their work engagement, autonomy and leadermember exchange. Teaching and Teacher Education, 30, 99-108.

Ryan, R. M. \& Deci, E. L. (2000). The darker and brighter sides of human existence: Basic psychological needs as a unifying concept. Psychological Inquiry, 11(4), 319338.

Schnittker, J. (2008). Happiness and success: Genes, families, and the psychological effects of socioeconomic position and social support. American Journal of Sociology, 114, 233-259.

Seligman, M. E. P. (2011). Flourish: A visionary new understanding of happiness and well-being. New York: Simon \& Schuster.

Seligman, M. E. P., Parks, A. C., \& Steen, T. (2004). A balanced psychology and a full life. Biological Sciences, 359(1449), 1379-1381.

Sezer, S., \& Can, E. (2019). School happiness: A scale development and implementation study. Eurasian Journal of Educational Research, 79, 167-190. 
Talebzadeh, F., \& Samkan, M. (2011). Happiness for our kids in schools: A conceptual model. Procedia-Social and Behavioral Sciences, 29(2011), 1462-1471.

Turner, J. C., Midgley, C., Meyer, D. K., Gheen, M., Anderman, E. M., Kang, Y. (2002). The classroom environment and students' reports of avoidance strategies in mathematics: A multimethod study. Journal of Educational Psychology, 94, 88-106.

Vähäsantanen, K., Hökkä, P., Eteläpelto, A., Rasku-Puttonen, H. \& Littleton, K. (2008). Teachers' professional identity negotiations in two different work organizations. Vocations and Learning, 1(2), 131-148.

Van Katwyk, P., Fox, S., Spector, P. E., \& Kelloway, E. (2000). Using the job-related affective wellbeing scale (JAWS) to investigate affective responses to work stressors. Journal of Occupational Health Psychology, 5, 219-230.

Veenhoven, R. (2008). Healthy happiness: Effects of happiness on physical health and the consequences for preventive health care. Journal of Happiness Studies, 9, 449-469.

Veenhoven, R. (2009). How do we assess how happy we are? In A. Dutt, A. Dutt, \& B. Radcliff (Eds.), Happiness, economics and politics (pp. 45-69). USA: Edward Elger Publishers (Chapter 3).

Webb, P. T. (2002). Teacher power: The exercise of professional autonomy in an era of strict accountability. Teacher Development, 6(1), 47-62.

Webb, R., Vulliamy, G., Hämäläinen, S., Sarja, A., Kimonen, E.,\& Nevalainen, R. (2004). Pressures, rewards and teacher retention: A comparative study of primary teaching in England and Finland. Scandinavian Journal of Educational Research, 48(2), 169-188.

Wright, K. B., Shields, S. M., Black, K., Banerjee, M., \& Waxman, H. C. (2018). Teacher perceptions of influence, autonomy, and satisfaction in the early Race to the Top era. Education Policy Analysis Archives, 26(62), 1-24.

Üzüm, P. (2014). Evaluation of classroom teachers awareness of teacher autonomy in terms of their structural and individual dimensions(Izmir province sample). Unpolished Doctoral Dissertation. Çanakkale Onsekiz Mart University.

Yazici, A. (2016). The relationship between the teacher autonomy and leaner autonomy support behaviour. Journal of Educational Sciences Research, 6(2), 1-23.

Yildirim, K. (2014). Main factors of teachers' professional well-being. Educational Research and Reviews, 9(6), 153-163.

Yucel, D., \& Vogt-Yuan, A. S. (2016). Parents, siblings, or friends? Exploring life satisfaction among early adolescents. Applied Research Quality Life, 11(4), 1399-1423.

Yu-hong, J. \& Ting, M. (2012). A review of the research on language teacher autonomy. Sino-US English Teaching, 9(4), 1045-1055. 